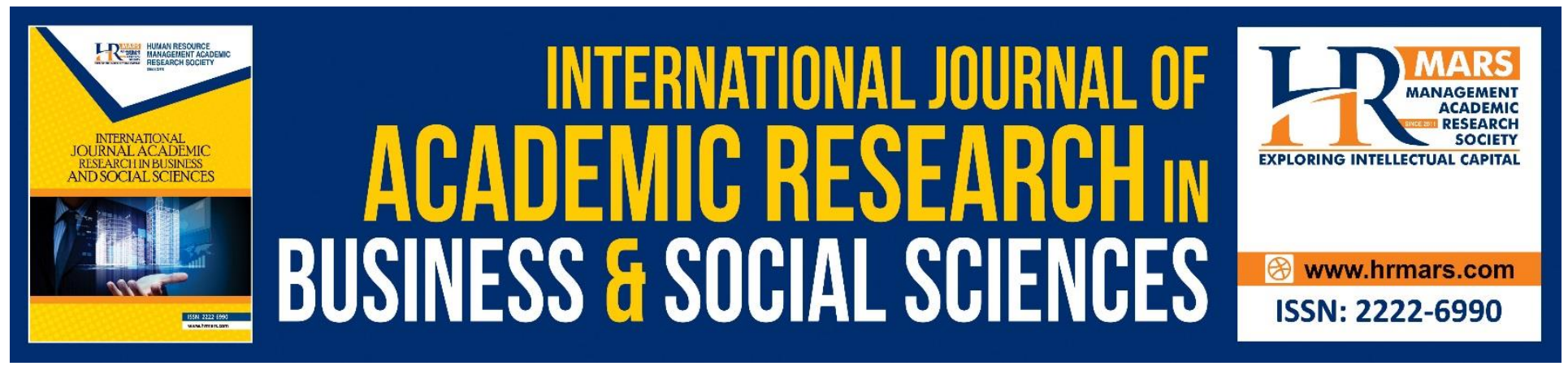

\title{
The Solfege Singing with Body Movement Skills of Preschool Children in Kodaly's Teaching Method
}

Loy Chee Luen, Aminah Ayob, Christine Augustine \& Colleen Wong

To Link this Article: http://dx.doi.org/10.6007/IJARBSS/v9-i1/5483

DOI: $\quad 10.6007 /$ IJARBSS/v9-i1/5483

Received: 15 Dec 2018, Revised: 13 Jan 2019, Accepted: 26 Jan 2019

Published Online: 01 Feb 2019

In-Text Citation: (Luen, Ayob, Augustine, \& Wong, 2019)

To Cite this Article: Luen, L. C., Ayob, A., Augustine, C., \& Wong, C. (2019). The Solfege Singing with Body Movement Skills of Preschool Children in Kodaly's Teaching Method. International Journal of Academic Research in Business and Social Sciences, 9(1), 811-820.

Copyright: @ 2019 The Author(s)

Published by Human Resource Management Academic Research Society (www.hrmars.com)

This article is published under the Creative Commons Attribution (CC BY 4.0) license. Anyone may reproduce, distribute, translate and create derivative works of this article (for both commercial and non-commercial purposes), subject to full attribution to the original publication and authors. The full terms of this license may be seen

at: http://creativecommons.org/licences/by/4.0/legalcode

Vol. 9, No. 1, 2019, Pg. 811 - 820

http://hrmars.com/index.php/pages/detail/IJARBSS

JOURNAL HOMEPAGE

Full Terms \& Conditions of access and use can be found at http://hrmars.com/index.php/pages/detail/publication-ethics 


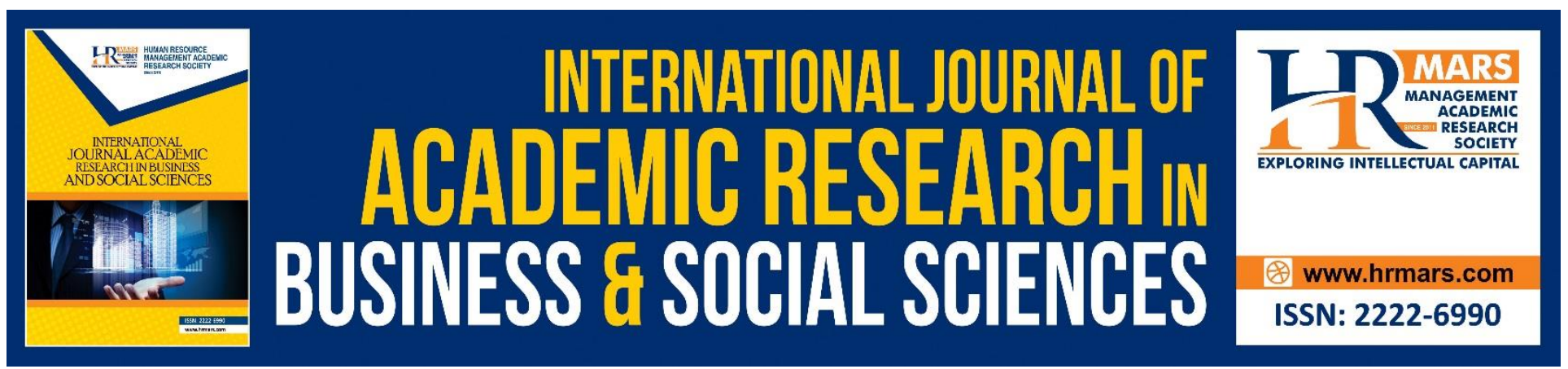

\title{
The Solfege Singing with Body Movement Skills of Preschool Children in Kodaly's Teaching Method
}

\author{
Loy Chee Luen \& Aminah Ayob
}

Department of Early Childhood Education, Faculty of Human Development, Universiti Pendidikan Sultan Idris, Malaysia.

\section{Christine Augustine \& Colleen Wong}

Department of Music and Music Education, Faculty of Music and Performing Arts,

Universiti Pendidikan Sultan Idris, Malaysia.

\begin{abstract}
The aim of this research is to identify the difference between children's solfege singing with body movement skills in terms of diction, pitch accuracy and rhythm between the treatment group and the control group. The solfege notations selected and evaluated in this research include (i) so mi and (ii) so mi la. The duration of this research is two weeks. Fifty children from two preschools were selected as respondents. This research adopts quasi-experimental design approach with one treatment group and one control group of twenty five children, respectively. The treatment group sang with body movements, while the control group sang without body movements. The research findings indicate that the Kodaly teaching method applying solfege singing with body movements is more effective to improve diction, pitch accuracy and rhythm compared to the teaching method without body movements. Solfege singing with body movements in Kodaly teaching method has given positive impact based on the fact that the solfege notation needs to be used to improve children's musical skills.
\end{abstract}

Keywords: Kodaly Teaching Method, Preschool, Children, Solfege Singing, Body Movements Skills

\section{Introduction}

The basic mechanics of Kodaly music teaching for children include solfege singing and the use of body movements to convey feelings and messages through songs (Kodaly, 1965; 1974). Solfege singing with body movements in Kodaly teaching method practised by early childhood educator is said to be able to increase preschool children's memory, kinesthetic abilities and singing skills. The Kodaly's musical activity helps teachers to achieve the objectives listed in the National Preschool Standard Curriculum (2016). 
The solfege singing system begins with the diatonic system. This system is useful for singing based around a fixed tonic in Kodaly method. Kodaly (1974) suggested that early childhood educator can teach children cultural knowledge, musical skills, focus and concentrate through songs. The solfege notations selected and evaluated in this research include (i) so mi and (ii) so mi la. Solfege singing with body movements helps children work on gross motor coordination and sequencing in musical activities (Devries, 2001; Loy, eta al. 2016; Loy, et al. 2017a; 2017b).

The aim of this research is to investigate the difference of children's solfege singing with body movement skills in terms of diction, pitch accuracy and rhythm between the treatment group and the control group.

\section{Literature Review}

The findings in Mock Garner (2011) research showed that educator must design singing and movement activities in teaching and learning process to help improve children's aural memory, oral precursors and kinesthetic skills. The data obtained in this research presented that kinesthetic learning activities play an important role in Kodaly-inspired music teaching method.

The research conducted by Entin (1990) found that integrating a Kodaly music curriculum into a developmental early childhood program based on theories of children's development and learning would help to fulfil the needs and learning requirements of preschool children. This program can improve children's musical development and skills. Besides, early childhood educators need to have knowledge and skills to apply Kodaly music teaching in their teaching and learning process.

In a research done by Bowyer (2015), it was found that Kodaly music teaching method has its own syllabus of rhythm singing and movements. Therefore, early childhood educators who put this method into practice should also take into account the appropriateness of the teaching aid and teaching plans that can meet the requirements and wishes of the children.

Moreover, the research carried out by Cozzutti et.al (2017) demonstrated that body solfege integrated with traditional solfege are able to encourage children's active and creative learning as well as increase their musical skills including instrument practice, solfege singing and body movements.

The study carried out by Loy, Aminah, Christine and Colleen (2016) demonstrated that children's solfege singing with body movements skills able to improve children's diction, pitch accuracy and rhythm in musical skills. Before the study is carried out, it is found that children have problems in musical skills. After the study, it is found that there is an improvement in the same set of skills. The findings for all these studies show that children's achievement in the solfege singing with body movements skills has improved after following Kodaly teaching method.

In sum, previous research studies have proven that Kodaly teaching method can help improve children's musical skills especially diction, pitch and rhythm. Therefore, this research is implemented by applying Kodaly music teaching method to improve children's solfege singing with body 
INTERNATIONAL JOURNAL OF ACADEMIC RESEARCH IN BUSINESS AND SOCIAL SCIENCES

Vol. 9, No. 1, Jan, 2019, E-ISSN: 2222-6990 (C) 2019 HRMARS

movements skills. Other than that, the diction, pitch accuracy and rhythm of the children are identified in this research.

\section{Methodology}

Two songs containing selected solfege notation are used in this research. The first song has a solfege notation of so mi whereas the second song has the notation of so mi la. A check list is used to identify the children's solfege singing with body movement skills.

\section{Song 1 (so-mi)}

\begin{tabular}{|c|c|c|c|c|c|c|c|c|c|c|c|}
\hline so & $\mathrm{mi}$ & so & $\mathrm{mi}$ & so & $\mathrm{mi}$ & so & $\mathrm{mi}$ & so & $\mathrm{mi}$ & so & $\mathrm{mi}$ \\
\hline fess) & (fes). & fess) & feses) & fess. & feses.) & (es) & fess.) & fess) & feses.) & fess. & (es) \\
\hline $\begin{array}{l}0.0 \\
\text { Sol }\end{array}$ & 凷 & $\begin{array}{l}\text { Hol } \\
\text { Sol }\end{array}$ & 㱐 & 㟧 & 㱐 & $\begin{array}{l}\text { Sol } \\
\text { Sol }\end{array}$ & हु है & $\begin{array}{l}\text { Wol } \\
\text { Sol }\end{array}$ & 㱐 & $\begin{array}{l}\text { o. } \\
\text { Sol }\end{array}$ & 密 \\
\hline
\end{tabular}

Song 2 (so-mi-la)

\begin{tabular}{|c|c|c|c|c|c|c|c|c|c|c|c|c|c|c|c|}
\hline so & $\mathrm{mi}$ & la & la & so & mi & la & la & so & mi & la & la & so & $\mathrm{mi}$ & la & la \\
\hline (fes) & (es) & (res) & (pes) & (fess) & (ees) & (pes) & (fes) & (fes) & (es) & (es) & (pes) & (es) & (eds) & (fess) & ess \\
\hline Sol & E्मुह & $\begin{array}{l}\text { Lib } \\
\text { La }\end{array}$ & La & $\begin{array}{l}\text { sol } \\
\text { Sol }\end{array}$ & ⿶凵木 & $\begin{array}{l}\text { La } \\
\text { La }\end{array}$ & $\begin{array}{l}\text { Le } \\
\text { La }\end{array}$ & Sol & 하용 & $\begin{array}{l}86 \\
\text { La }\end{array}$ & $\begin{array}{l}\text { Su } \\
\text { La }\end{array}$ & $\begin{array}{l}\text { sol } \\
\text { Sol }\end{array}$ & ثิن & $\begin{array}{l}\text { 㟧 } \\
\text { La }\end{array}$ & $\begin{array}{l}\text { 㟧 } \\
\text { La }\end{array}$ \\
\hline
\end{tabular}

The duration of this research is two weeks. Fifty children from two preschools were selected as respondents. This research adopts quasi-experimental design approach with treatment group and control group of twenty five children, respectively. The treatment group sang using body movements whereas the control group sang without body movements.

\section{Finding}

The research finding demonstrates that Kodaly teaching method of applying solfege singing with body movements is more effective to increase the skills of diction, pitch accuracy and rhythm compared to the teaching method without body movements.

1. Solfege Singing with Body Movements with Notation so-mi In Terms of Diction 
INTERNATIONAL JOURNAL OF ACADEMIC RESEARCH IN BUSINESS AND SOCIAL SCIENCES Vol. 9, No. 1, Jan, 2019, E-ISSN: 2222-6990 (C) 2019 HRMARS

Table 1

The t-test results for independent respondents concerning solfege singing with body movement skills in terms of diction for children taught with solfege singing with body movements and without body movements.

\begin{tabular}{lllllll}
\hline $\begin{array}{l}\text { Construct } \\
\text { (Dependent } \\
\text { Variable) }\end{array}$ & $\begin{array}{l}\text { Factor } \\
\text { (Independent Variable) }\end{array}$ & N & Mean & SD & t & Sig \\
\hline Diction & Body movements & 25 & 2.00 & .000 & 6.000 & .000 \\
& Without body movements & 25 & 1.40 & .500 & & \\
\hline
\end{tabular}

Table 1 shows respondents' independent t-test that was carried out to compare the solfege singing skills in terms of diction for children taught with solfege singing with body movements and without body movements. The analysis result shows there is a difference between solfege singing skills with body movements in terms of diction taught with and without the body movements. Children taught with body movements achieved the mean of 2.00 and $\mathrm{SD}=.000$ whereas children taught without body movements achieved the mean of 1.40 and SD $=.500$. The t-test findings suggest that teaching with body movements is more effective compared to teaching without body movements, in terms of diction.

2. Solfege Singing with Body Movements with Notation so-mi In Terms of Pitch Accuracy

Table 2

The t-test results for independent respondents concerning solfege singing with body movements skills in terms of pitch accuracy for children taught with solfege singing with body movement and without body movements.

\begin{tabular}{|c|c|c|c|c|c|c|}
\hline $\begin{array}{l}\text { Construct } \\
\text { (Dependent } \\
\text { Variable) }\end{array}$ & $\begin{array}{l}\text { Factor } \\
\text { (Independent Variable) }\end{array}$ & $\mathrm{N}$ & Mean & SD & $\mathrm{t}$ & Sig \\
\hline \multirow[t]{2}{*}{ Pitch Accuracy } & Body movements & 25 & 1.60 & .500 & 3.523 & .001 \\
\hline & Without body movements & 25 & 1.16 & .374 & & \\
\hline
\end{tabular}

Table 2 shows respondents' independent t-test that was carried out to compare the solfege singing skills in terms of pitch accuracy for children taught with solfege singing with body movements and without body movements. The result of the analysis establishes that there is a difference in the 
INTERNATIONAL JOURNAL OF ACADEMIC RESEARCH IN BUSINESS AND SOCIAL SCIENCES

Vol. 9, No. 1, Jan, 2019, E-ISSN: 2222-6990 (C) 2019 HRMARS

achievement of solfege singing with body movement skills in terms of pitch accuracy between the two groups of children. Children taught with body movements achieved the mean of 1.60 and SD = .500 while children taught without body movements achieved the mean of 1.16 and SP $=.374$. The finding of the t-test suggests that teaching with body movements is more effective compared to teaching without body movements, in terms of pitch accuracy.

3. Solfege Singing with Body Movements with Notation so-mi In Terms of Rhythm

Table 3

The t-test results for independent respondents concerning the solfege singing with body movement skills in terms of rhythm for children taught with solfege singing with body movements and without body movements.

\begin{tabular}{lllllll}
\hline $\begin{array}{l}\text { Construct } \\
\text { (Dependent } \\
\text { Variable) }\end{array}$ & $\begin{array}{l}\text { Factor } \\
\text { (Independent Variable) }\end{array}$ & N & Mean & SD & t & Sig \\
\hline \multirow{2}{*}{ Rhythm } & Body movements & 25 & 1.88 & .332 & 4.000 & .000 \\
& Without body movements & 25 & 1.40 & .500 & & \\
\hline
\end{tabular}

Table 3 shows respondents' independent t-test carried out to compare solfege singing skills in terms of rhythm for children taught with body movements and without body movements. The results of the analysis establish that there is a difference in the achievement of solfege singing skills between the two groups of children. The children taught with body movements achieved the mean of 1.88 and SD $=.332$ while the children taught without body movements achieved the mean of 1.40 and SD $=.500$. The finding of the t-test concerning rhythm suggests that teaching with body movements is more effective compared to teaching without body movements. 
INTERNATIONAL JOURNAL OF ACADEMIC RESEARCH IN BUSINESS AND SOCIAL SCIENCES

Vol. 9, No. 1, Jan, 2019, E-ISSN: 2222-6990 C 2019 HRMARS

\section{Solfege Singing with Body Movements with Notation so-mi-la In Terms of Diction}

Table 4

The t-test results for independent respondents concerning solfege singing with body movement skills in terms of diction for children taught with solfege singing with body movements and without body movements.

\begin{tabular}{lllllll}
\hline $\begin{array}{l}\text { Construct } \\
\text { (Dependent } \\
\text { Variable) }\end{array}$ & $\begin{array}{l}\text { Factor } \\
\text { (Independent Variable) }\end{array}$ & N & Mean & SD & t & Sig \\
\hline & & & & & & \\
Diction & Body movements & 25 & 1.84 & .374 & 6.425 & .000 \\
& Without body movements & 25 & 1.16 & .374 & & \\
\hline
\end{tabular}

Table 4 shows respondents' independent t-test that was carried out to compare the solfege singing with body movements in terms of diction for children taught with solfege singing with body movements and without body movements. Analysis of the results shows there is a difference between the solfege singing skills in terms of diction taught with and without body movements. Children taught with body movements achieved the mean of 1.84 and SD $=.374$ and for children taught without body movements, they achieved the mean of 1.16 and SD $=.374$. The finding of the t-test suggests that teaching with body movements is more effective compared to teaching without body movements, in terms of diction.

5. Solfege Singing with Body Movements with Notation so-mi-la In Terms of Pitch Accuracy

Table 5

The t-test results for independent respondents concerning solfege singing with body movements in terms of pitch accuracy for children taught with solfege singing with body movements and without body movements.

\begin{tabular}{lllllll}
\hline $\begin{array}{l}\text { Construct } \\
\text { (Dependent } \\
\text { Variable) }\end{array}$ & $\begin{array}{l}\text { Factor } \\
\text { (Independent Variable) }\end{array}$ & N & Mean & SD & t & Sig \\
\hline \multirow{2}{*}{$\begin{array}{l}\text { Pitch Accuracy } \\
\text { Body movements }\end{array}$} & 25 & 1.59 & .485 & 2.311 & .001 \\
& Without body movements & 25 & 1.35 & .479 & & \\
\hline
\end{tabular}

Table 5 shows respondents' independent t-test that was carried out to compare the solfege singing with body movements in terms of pitch accuracy for children taught with solfege singing with body movements and without body movements. The analysis result finds that there is a difference 
INTERNATIONAL JOURNAL OF ACADEMIC RESEARCH IN BUSINESS AND SOCIAL SCIENCES

Vol. 9, No. 1, Jan, 2019, E-ISSN: 2222-6990 (C) 2019 HRMARS

between the solfege singing skills in terms of diction taught with and without body movements. Children taught with hand signals achieved the mean of 1.59 and SD $=.485$ and for children taught without body movements, they achieved the mean of 1.35 and SD $=.479$. The findings of the t-test suggest that teaching with body movements is more effective compared to teaching without body movements, in terms of pitch accuracy.

6. Solfege Singing with Body Movements with Notation so-mi-la In Terms of Rhythm

Table 6

The t-test results for independent respondents concerning the solfege singing with body movements in terms of rhythm for children taught with solfege singing with body movements and without body movements.

\begin{tabular}{lllllll}
\hline $\begin{array}{l}\text { Construct } \\
\text { (Dependent } \\
\text { Variable) }\end{array}$ & $\begin{array}{l}\text { Factor } \\
\text { (Independent Variable) }\end{array}$ & N & Mean & SD & t & Sig \\
\hline \multirow{2}{*}{ Rhythm } & Body movements & 25 & 1.86 & .329 & 3.972 & .000 \\
& Without body movements & 25 & 1.39 & .489 & & \\
\hline
\end{tabular}

Table 6 shows respondents' independent t-test that was carried out to compare the solfege singing skills in terms of rhythm for children taught with solfege singing with body movements and without body movements. The results analysis shows that there is a difference between the solfege singing skills in terms of rhythm, taught with and without body movements. Children taught with body movements achieved the mean of 1.86 and SD $=.329$ and for children taught without body movements, they achieved the mean of 1.39 and SD $=.489$. The findings of the t-test suggest that teaching with body movements is more effective compared to teaching without body movements, in terms of rhythm.

\section{Discussion}

In terms of the notation so-mi in solfege singing with body movements, in general, it has proven that Kodaly music teaching method with body movements is more effective to improve the skills of solfege singing in terms of diction, pitch accuracy and rhythm compared to the teaching without body movements.

In terms of the notation so-mi-la in solfege singing, in general, it has proven that Kodaly music teaching method with body movements is more effective to improve the skills of solfege singing in terms of diction, pitch accuracy and rhythm compared to the teaching without body movements. 


\section{Conclusion}

This study focuses on children's solfege singing with body movement skills in terms of diction, pitch accuracy and rhythm under the Kodaly music teaching method. The contribution of this research is to provide the Kodaly music teaching method to improve children's musical skills. The research findings show that solfege singing with body movement skills for both notations of so-mi and so-mila under the Kodaly music teaching method are more effective to improve solfege singing compared to the teaching method without body movements. Body solfege integrated with traditional solfege are able to increase children's solfege singing and body movements skills. In further research, researchers will test solfege singing with musical drinking glasses, musical piano map and play piano in phone in children's music lesson.

\section{Acknowledgement}

The researchers would like to acknowledge the Research Management and Innovation Centre, Universiti Pendidikan Sultan Idris for the University Research Grant (2015-0148-107-01).

\section{Corresponding Author}

Dr. Loy Chee Luen

Associate Professor

Department of Early Childhood Education

Faculty of Human Development

Universiti Pendidikan Sultan Idris

Perak Malaysia

Email: loy.cl@fpm.upsi.edu.my

\section{References}

Bowyer, J. (2015). More than solfege and hand signs: Philosophy, tools and lesson planning in the authentic Kodaly classroom. Music Educators Journal, 102.2: 69.

Cozzutti, G., Blessano, E., De Biaggio, C. D., Tomasin, B. \& Romerro-Naranjo, F. J. (2016). Body solfege in the BAPNE method-Measures and divisions. Procedia Social and Behavioral Science 237 (2017) 1572-1575.

Devries, P. (2001). Reevaluating common Kodaly practices. Music Educators Journal, Nov. 2001: 24.

Entin, P. (1990). Integrating a Kodaly music curriculum into a developmental early childhood program. Theses. United State: Virginia Commonwealth University.

Kementerian Pendidikan Malaysia. (2016). Kurikulum Standard Prasekolah Kebangsaan. Putrajaya: Ministry of Education Malaysia.

Kodaly, Z. (1965). Let us sing correctly. London: Boosey \& Hawkes.

Kodaly, Z. (1974). The selected writings of Zoltan Kodaly. London: Boosey \& Hawkes.

Loy, C.L., Aminah, A., Wong, C. \& Christine, A. (2016). Mencipta lagu-lagu bertema untuk menilai kemahiran nyanyian dan gerakan solfa kanak-kanak. Geran Universiti. Tanjung Malim: Universiti Pendidikan Sultan Idris. 
Loy, C.L., Aminah, A., Wong, C. \& Christine, A. (2017). Kodaly's teaching method increasing preschool children's solfege singing skills. International Journal of Academic Research in Business and Social Sciences. Vol.7, No.3. 340-347.

Loy, C.L., Aminah, A., Wong, C. \& Christine, A. (2017). Kaedah Kodaly dalam pengajaran muzik kanakkanak. In Mahizer, H., Noraijni, M.N. \& Norazilawati, A. (ed). Trend dan Isu. Vol. 4. No.1. 29-35.

Mock Garner, L. A. (2011). Pedagogy in practice: Lived experiences of Kodaly inspired music educators. Dissertation. Minnesota: University of St. Thomas. 